\title{
Evaluation of Seaweeds Ulva rigida and Pterocladia capillaceaas Dietary Supplements in Nile Tilapia Fingerlings
}

\section{Malik M Khalafalla ${ }^{1 *}$ and Abd-elaziz M A El-Hais ${ }^{2}$}

${ }^{1}$ Department of Aquaculture, Faculty of Aquatic and Fisheries Sciences, Kafrelsheikh University, 33516-Kafr El-sheikh, Egypt ${ }^{2}$ Department of Animal Production, Faculty of Agriculture, Tanta University, Egypt

\begin{abstract}
The present study was carried out to investigate the effect of green algae Ulva lactuca and red algae Pterocladia capillacea at $0.0,2.5$ and $5 \%$ on growth performance, feed utilization, carcass composition and blood indices of Nile tilapia, Oreochromis niloticus fingerlings. Fish $(18.47 \pm 1.25 \mathrm{gm})$ were randomly divided into fifteen aquaria in triplicates and fed diets contained about $29.51 \%$ total protein and $4.53 \mathrm{kcal} / \mathrm{g}$ gross energy. All the growth performance parameters and feed utilization values of experimental fish were increased significantly $(P \leq 0.05)$ by both of algae supplementation. Diet supplemented with $5 \%$ of Ulva lactuca had acceptable growth parameters compared with other diets. Fish fed supplemented diets had slight increases and decreases for carcass protein and lipids without significant differences $(P \geq 0.05)$. Also, no significant differences $(P>0.05)$ were obtained for serum total protein, albumin and globulin and liver activity. It may be summarized that, algae supplementation especially at $5 \%$ of Ulva lactuca level may improves growth parameters and carcass composition without adverse effects on blood metabolites and liver activity.
\end{abstract}

Keywords: Algae; Growth Performance; Nile Tilapia

\section{Introduction}

The demand for feeds which are safer and effective than the traditional animal products especially plant origin ingredients mainly terrestrial and sometimes aquatic has recently renewed and increasing for aquafeeds preparation. Edible seaweeds or algae are a renewable natural resource existing in large quantities all along the Pacific coast.

In general, seaweeds are not considered a good source of PUNSFA [1], and the total lipid content has always been found to be greater than $4 \%$ [2], but their polyunsaturated fatty acids content can be equal to land plants content [3]. Besides that, seaweeds are not a main source of energy but they had a high nutritional value which related with acceptable vitamin, protein and mineral contents [4,5]. It is said that $100 \mathrm{~g}$ of seaweed provides more than the daily requirement of vitamin $\mathrm{A}, \mathrm{B} 2$ and $\mathrm{B} 12$ and two thirds of the vitamin $\mathrm{C}$ requirement [6]. In addition to, seaweeds are an important source of dietary fiber, mainly soluble fiber [7], which is considered an important component for preventing constipation, colon cancer, cardiovascular disease and obesity, among others. The potential of algae as an alternate protein or feed supplement ingredient in aquatic feeds is currently being examined in many regions of the world [8], because of their high protein content and fast growth rate [9].

The green alga Ulva lactuca (Chlorophyta) and red alga Pterocladia capillacea (Rhodophyta) are among the dominant macroalgae along the Egyptian Mediterranean coast all the year around. They grow near the water level, in large amounts, and can easily be harvested by hand, from natural populations. In recent years, Ulva species have become important macroalgae, which have been investigated as a dietary ingredient for a wide range of fish species. Low-level dietary incorporation of Ulva meal has resulted in improved growth, feed utilization, physiological activity, disease resistance, carcass quality, and reduced stress response $[10,11]$. Ulva as one of seaweeds have a good vitamin and mineral profile and are especially rich in ascorbic acid [12,13]. Moreover, recent studies on Ulva meal addition in Nile tilapia [14] and rainbow trout diets [15] have been accepted to be good supplements for fish feeding. Also, many researchers have studied the composition and the properties of polysaccharides from the red algae Pterocladia capillacea. Pterocladia as a red algae genus is used for industrial production of gelling galactans and is commonly distributed in the seas of Lebanon, Egypt, Brazil, Italy and other countries [16,17].

The Nile tilapia Oreochromis niloticus still the most widely cultured species of tilapia in Africa. Tilapia had positive aquacultural characteristics, adaption with their tolerance to poor water quality and resistance to viral, bacterial and parasitic diseases compared to other cultured fish, especially in Egypt at optimum temperatures for growth. Moreover, tilapia ingests a wide variety of natural food organisms. So, tilapia is a suitable fish to maximize production and meet human nutrition requirements under different culture conditions.

The purpose of the present study was to evaluate the nutritional value of the Ulva lactuca and Pterocladia capillacea species and their effects on feeding efficiency, growth performance, body composition and blood components of Nile tilapia fingerlings.

\section{Material and Methods}

This work was carried out at the Wet Fish Lab., Department of Animal Production, Faculty of Agriculture, Kafr elsheikh University, Egypt, during summer season, 2014.

\section{Experimental fish}

Nile tilapia fingerlings were bought from the private fish farm

*Corresponding author: Malik M. Khalafalla, Department of Aquaculture, Faculty of Aquatic and Fisheries Sciences, Kafrelsheikh University, 33516-Kafr El-sheikh Egypt, Tel: +20-1064120013; E-mail: malikkhalafalla@yahoo.com

Received December 06, 2014; Accepted December 29, 2014; Published January 31,2015

Citation: Khalafalla MM, El-Hais AMA (2015) Evaluation of Seaweeds Ulva rigida and Pterocladia capillaceaas Dietary Supplements in Nile Tilapia Fingerlings. J Aquac Res Development 6: 312. doi:10.4172/2155-9546.1000312

Copyright: $\odot 2015$ Khalafalla MM, et al. This is an open-access article distributed under the terms of the Creative Commons Attribution License, which permits unrestricted use, distribution, and reproduction in any medium, provided the original author and source are credited. 
at Tolompate 7, Kafr El-Sheikh governorate. Prior to the start of the experiment, fingerlings were placed in a fiberglass tank and randomly distributed into glass aquaria to be adapted to the experimental condition until starting the experiment. All fish were fed the control diet during the first 7 days after stocking to adapt them to feeding and handling practices. After that, the fish were fed the experimental diets.

\section{Experimental design of rearing fish}

Fish $(\mathrm{n}=150 ; 18.47 \pm 1.25 \mathrm{gm})$ were randomly divided into fifteen $(70 \mathrm{~L})$ aquaria in triplicates (10 fish per replication). One third of water aquaria were replaced daily and totally once every week after removing the wastes. Fresh tap water was stored in fiberglass tanks for $24 \mathrm{~h}$ under aeration for chlorination. Fifteen air stones were used for aerating the aquaria water. All aquaria were maintained under a constant photoperiod (12 h dark: $12 \mathrm{~h}$ light) created by fluorescent lamps. Fish feces and feed residue were removed daily by siphoning

\section{Experimental diets and feeding regime}

Prior to the start of the experiment, the fish were adapted to a basal commercial diet [control diet (D1)] containing $29.55 \%$ crude protein (Table 2) for two weeks. Five experimental commercial diets were formulated to contain $0,2.5$ and $5 \%$ of green algae Ulva lactuca and red algae Pterocladia capillacea.

Algae were obtained from the Egyptian Mediterranean coast of Alexandria. The chemical analysis of Ulva lactuca and Pterocladia capillacea is presented in Table 1. A basal diet was formulated using the commercial ingredients. The dry ingredients were finely grounded and mixed by a dough mixer for 20 minutes for homogeneity. Oil was gradually added while mixing. After homogenous mixture, $40 \mathrm{ml}$ water per 100 gm diet. Diet was slowly added to the mixture according to Shimeino et al. [18].

The diets were cooked on the water evaporator for 20 minutes and pelleted $(3 \mathrm{~mm})$ through fodder machine and the manufacture pellets were dried on oven at $70^{\circ} \mathrm{C}$ for 48 hours. The diets collected, tagged and stored in refrigerator at $4^{\circ} \mathrm{C}$. Fish in all treatment were daily fed the experimental diets at a level of 5, 4 and $3 \%$ of the body weight daily for the first, the second and the third four weeks, respectively.

Feed amount was given three times daily $(900,1200$ and 1500) in equal portions, six days a week for 12 weeks. Fish were weighed

\begin{tabular}{|c|c|c|}
\hline Chemical composition & Ulva lactuca & Petrocladia capillacea \\
\hline DM & 80.98 & 79.01 \\
\hline CP & 20.33 & 18.92 \\
\hline CF & 9.87 & 12.02 \\
\hline EE & 3.21 & 2.74 \\
\hline NFE & 48.34 & 44.99 \\
\hline ASH & 17.98 & 20.95 \\
\hline ADF & 38.85 & 40.43 \\
\hline ADL & 24.67 & 26.03 \\
\hline Hemicellulose & 7.67 & 8.01 \\
\hline Cellulose & 14.01 & 14.36 \\
\hline Calories, kcal & 17.13 & 17.78 \\
\hline Minerals composition & 303.54 & 282.24 \\
\hline Sodium & & \\
\hline Potassium & 195.8 & 205.1 \\
\hline Calcium & 96.9 & 64.9 \\
\hline Magnesium & 69.8 & 196.5 \\
\hline
\end{tabular}

Table 1: Chemical composition of Ulva lactuca and Pterocladia capillacea.

\begin{tabular}{|c|c|c|c|c|c|}
\hline \multirow{2}{*}{ Ingredients } & \multicolumn{5}{|c|}{ Diet $^{6}$ No. } \\
\hline & D1 & D2 & D3 & D4 & D5 \\
\hline Fish meal & 100 & 100 & 100 & 100 & 100 \\
\hline Soybean meal & 380 & 375 & 380 & 375 & 380 \\
\hline Yellow corn & 200 & 200 & 200 & 200 & 200 \\
\hline Wheat bran & 120 & 100 & 100 & 100 & 100 \\
\hline Rice bran & 150 & 150 & 120 & 150 & 120 \\
\hline Oil mixture $^{1}$ & 30 & 30 & 30 & 30 & 30 \\
\hline Vitamin and mineral premix ${ }^{2}$ & 20 & 20 & 20 & 20 & 20 \\
\hline Ulva lactuca & 0 & 25 & 50 & 0 & 0 \\
\hline Pterocladia capillacea & 0 & 0 & 0 & 25 & 50 \\
\hline Total & 1000 & 1000 & 1000 & 1000 & 1000 \\
\hline \multicolumn{6}{|c|}{ Proximate composition and energy content ( $\%$ dry matter basis) } \\
\hline Dry matter & 90.35 & 90.54 & 90.41 & 90.45 & 90.38 \\
\hline Crude protein & 29.55 & 29.48 & 29.62 & 29.42 & 29.50 \\
\hline Crude lipid & 8.97 & 8.87 & 8.76 & 8.66 & 8.57 \\
\hline Crude fiber & 5.43 & 5.64 & 5.78 & 5.86 & 6.05 \\
\hline Crude ash & 7.54 & 7.64 & 7.87 & 8.12 & 8.20 \\
\hline Nitrogen free extract & 48.51 & 48.37 & 47.97 & 47.94 & 47.68 \\
\hline $\mathrm{GE}$ (kcal/kg diet) ${ }^{3}$ & 456.4 & 454.5 & 452.6 & 450.5 & 448.9 \\
\hline $\mathrm{DE}(\mathrm{kcal} / \mathrm{kg} \mathrm{diet})^{4}$ & 342.3 & 340.9 & 339.5 & 337.9 & 336.7 \\
\hline $\mathrm{P} / \mathrm{E}$ ratio (mg CP/kcal DE) ${ }^{5}$ & 86.4 & 86.5 & 87.2 & 87.1 & 87.6 \\
\hline
\end{tabular}

${ }^{1}$ Mixture of sunflower oil and linseed oil with a ratio of $1: 1$.

${ }^{2}$ Commercial vitamin (Super Vit, Arab Veterinary Industrial Co., Jordan). 15,000 IU vitamin A, $0.7 \mathrm{~g}$ vitamin C (Stay $\mathrm{C} \circledast, 35 \%$ active), 15,000 IU vitamin D3, $2 \mathrm{mg}$ vitamin $\mathrm{E}, 2.5 \mathrm{mg}$ vitamin $\mathrm{B} 2,2 \mathrm{mg}$ vitamin $\mathrm{K} 3,10 \mathrm{mg}$ nicotineamide, $3 \mathrm{mg}$ vitamin B6, $5 \mathrm{mg}$ vitamin B12, $2 \mathrm{mg}$ vitamin B1, $2 \mathrm{mg}$ folic acid, $5.5 \mathrm{mg}$ Ca-D-pantothenate and mineral premix (Eco Vit, Egyptian Veterinary Produced and Feed a Additives Co., Demyatta, Egypt). $200 \mathrm{~g}$ calcium, $90 \mathrm{~g}$ phosphate, $40 \mathrm{~g}$ sodium, $2.5 \mathrm{~g}$ copper, $48 \mathrm{~g}$ magnesium, $3.6 \mathrm{~g}$ manganese, $23.5 \mathrm{~g}$ zinc, $8 \mathrm{~g}$ iron, $450 \mathrm{mg}$ cobalt, $200 \mathrm{mg}$ iodine and $20 \mathrm{mg}$ selenium.

${ }^{3} \mathrm{GE}$ (Gross energy) was calculated according to NRC [19] by using factors of $5.65,9.45$ and $4.22 \mathrm{~K}$ cal per gram of protein, lipid and carbohydrate, respectively. ${ }^{4} \mathrm{DE}$ (Digestible energy) was calculated by applying the coefficient of 0.75 to convert gross energy to digestible energy according to Hepher et al. [20]

${ }^{5} \mathrm{P} / \mathrm{E}$ (protein energy ratio)=crude protein $\times 1000 /$ digestible energy $/ 100 \mathrm{~g}$, according to Hepher et al. [20].

${ }^{6}$ Diets: D1 (control): without supplements, D2: $2.5 \%$ Ulvalactuca, D3:5\% Ulvalactuca and D4: 2.5\% Pterocladiacapillacea and D5 5\% Pterocladiacapillacea.

${ }^{*}$ Values of diets content were within the range suggested for tilapia by Jauncey and Ross [21] and NRC [19].

Table 2: Formulation and chemical proximate composition of the experimental diets $(\mathrm{g} / \mathrm{kg}$ dry weight basis).

biweekly and feed amounts were adjusted on the basis of the new weight. Mortality was monitored daily and recorded.

\section{Analytical procedures}

Moisture, crude protein (\% $\mathrm{N}$ x 6.25), crude lipid, crude fiber and ash contents of diet ingredients and a sample of fish at the beginning and end of the experiment were determined in triplicate according to A.O.A.C [19-22]. Gross energy (GE) contents of the experimental diets and fish samples were calculated by using factors of 5.65, 9.45 and 4.22 $\mathrm{kcal} / \mathrm{g}$ of protein, lipid and carbohydrates, respectively [19].

\section{Measurements of water parameters}

Water samples were taken each two days for ammonia and $\mathrm{pH}$ analysis. Analytical methods were done according to the American Public Health Association (APHA) [23]. Water temperature and oxygen level were measured daily at 8 o'clock by (Oxygen meter model 9070). In all treatments water quality parameters for water temperature ranged between 27.00 to $28.00^{\circ} \mathrm{C}, \mathrm{pH}$ ranged from 7.01 to 7.25 ; dissolved oxygen ranged from 5.75 to $6.12 \mathrm{mg} / \mathrm{L}$ and water 
Citation: Khalafalla MM, El-Hais AMA (2015) Evaluation of Seaweeds Ulva rigida and Pterocladia capillaceaas Dietary Supplements in Nile Tilapia Fingerlings. J Aquac Res Development 6: 312. doi:10.4172/2155-9546.1000312

Page 3 of 5

ammonia ranged from 0.06 to $0.09 \mathrm{mg} / \mathrm{L}$. In general, all the water quality parameters were within the acceptable ranges for fish growth.

\section{Measurements of growth and feed utilization parameters}

Body weight of fish in each aquarium was measured at start and every two weeks during the experimental period (12 weeks). Diet performance was evaluated as follows:

Average weight gain AWG (g/fish) $=\mathrm{Wt}-\mathrm{W} 0$.

Average daily weight gain ADG (g/fish/day) $=\mathrm{Wt}-\mathrm{W} 0 / \mathrm{t}$.

Specific growth rate $\%$ day SGR $(\% /$ day $)=100 \times(\mathrm{In} \mathrm{Wt}-\mathrm{InW} 0) / \mathrm{t}$

${ }^{* *}$ Where $\mathrm{Wt}$ is weight of fish at time $\mathrm{t}, \mathrm{W} 0$ is weight of fish at time 0 , and $t$ is the experimental period in days.

\section{Feed conversion ratio, FCR=dry feed fed/wet weight gain.}

Protein efficiency ratio, PER=wet weight gain/ Protein fed. fed).

Protein productive value, PPV $(\%)=100 \times($ protein gain/protein

Survival rate, $S R=100$ (Total No. of fish at the end of the experimental/Total No. of fish at the start of the experiment].

ER $(\%)=(\%$ Energy in fish carcass $(\mathrm{kcal})$ at the end-Energy in fish carcass $(\mathrm{kcal})$ at the start $) \times 100 /$ Energy intake $(\mathrm{kcal})$

\section{Blood parameters determination}

At the end of the experiment fish in each aquaria were weighed and three blood samples were taken randomly from the caudal vein for blood analysis and differential leukocyte count, Anti coagulated blood samples were prepared immediately for counting red and white blood cells etc. Red blood cells count $\left(\mathrm{RBCs} \times 10^{6} / \mathrm{mm}^{3}\right)$ and white blood cells count $\left(\mathrm{WBCs} \times 10^{3} / \mathrm{mm}^{3}\right)$ : were measured on an A brightline Haemocytometer model (Neubauer improved, Precicolor HBG, Germany) by using a commercial kits (Ranox company, Germany) according to the method described by Stoskopf [24]. Hemoglobin concentration $(\mathrm{Hbgm} / \mathrm{dl})$ : was determined according to the method of Zinkl [25]. Packed cell volume (PCV \%): was estimated by the microhaematocrite method as described by Dacie and Lewis [26]. A total protein (TP) was measured according to the method of Henry [27] using reagent kits obtained from Diamond Diagnostic Company (Egypt). ALT (U|L) and AST (U|L): Alanine Aminotransferase (ALT) and Aspartate Aminotransferase (AST) activities were assayed according to the method of Reitman and Frankel [28] using reagent kits purchased from Randox Company (UK).

\section{Statistical analysis}

The obtained numerical data were statistically analyzed using SPSS [29] for one-way analysis of variance. When F-test was significant, least significant difference was calculated according to Duncan [30].

\section{Results and Discussion}

Growth performance parameters of Nile tilapia (O. niloticus) fed on the experimental diets is presented in Table 3.

The data of the present study showed that, final body weight (FBW), average total gain (ATG), average daily gain (ADG), and specific growth rate (SGR) of experimental fish were influenced significantly $(\mathrm{P} \leq 0.05)$ by different levels of Ulva lactuca and Pterocladia capillacea algae. Fish fed on diet supplemented with 5\% Ulva lactuca (D3) had higher increases of growth parameters as FBW, ATG, ADG and

\begin{tabular}{|c|c|c|c|c|c|c|}
\hline \multirow[t]{2}{*}{ Items } & \multicolumn{5}{|c|}{ Diets No (On DM basis, \%) } & \multirow[b]{2}{*}{$\mathrm{SE}^{*}$} \\
\hline & $\begin{array}{c}\mathrm{D}_{1} \\
\text { Control }\end{array}$ & $D_{2}$ & $\mathrm{D}_{3}$ & $\mathrm{D}_{4}$ & $D_{5}$ & \\
\hline Initial weight, g/fish & 18.57 & 18.24 & 18.67 & 18.35 & 18.55 & 1.25 \\
\hline Final body weight, g/fish & $47.52^{\mathrm{c}}$ & $55.86^{\mathrm{ab}}$ & $60.45^{\mathrm{a}}$ & $53.54^{b}$ & $55.28^{\mathrm{ab}}$ & 2.31 \\
\hline Average total gain ${ }^{1}, \mathrm{~g} / \mathrm{fish}$ & $28.95^{\mathrm{c}}$ & $37.62^{\mathrm{ab}}$ & $41.78^{a}$ & $35.19^{b}$ & $36.73^{\mathrm{ab}}$ & 1.54 \\
\hline $\begin{array}{l}\text { Average daily gain }{ }^{2}, \mathrm{~g} / \\
\text { fish/day }\end{array}$ & $0.34^{c}$ & $0.45^{\mathrm{ab}}$ & $0.50^{\mathrm{a}}$ & $0.42^{b}$ & $0.44^{\mathrm{ab}}$ & 0.01 \\
\hline $\begin{array}{l}\text { Specific growth rate }{ }^{3} \text { (SGR } \\
\% / \text { day) }\end{array}$ & $1.12^{c}$ & $1.33^{\mathrm{b}}$ & $1.39^{\mathrm{a}}$ & $1.27^{\mathrm{bc}}$ & $1.30^{\mathrm{b}}$ & 0.30 \\
\hline Survival rate $4, \%$ & 97 & 97 & 100 & 97 & 100 & 3.12 \\
\hline Feed intake (FI), DM g/fish & 55.76 & 56.98 & 57.24 & 58.50 & 57.36 & 2.41 \\
\hline $\begin{array}{l}\text { Feed conversion ratio } \\
\text { (FCR) }\end{array}$ & $1.74^{\mathrm{a}}$ & $1.37^{\circ}$ & $1.24^{d}$ & $1.50^{\mathrm{b}}$ & $1.41^{\mathrm{c}}$ & 0.31 \\
\hline $\begin{array}{l}\text { Protein efficiency ratio }{ }^{6} \\
\text { (PER) }\end{array}$ & $1.94^{\mathrm{d}}$ & $2.47^{\mathrm{b}}$ & $2.73^{\mathrm{a}}$ & $2.26^{c}$ & $2.40^{\mathrm{b}}$ & 0.45 \\
\hline $\begin{array}{l}\text { Protein productive value }{ }^{7} \\
\text { (PPV, \%) }\end{array}$ & $13.10^{\mathrm{c}}$ & $15.32^{b}$ & $17.87^{\mathrm{a}}$ & $12.78^{c}$ & $15.70^{\mathrm{b}}$ & 1.14 \\
\hline
\end{tabular}

*Means in the same rows having different superscript letters were significantly different at 0.05 levels

Table 3: Growth performance parameters of Nile tilapia (O. niloticus) fed on the experimental diets.

SGR compared to other experimental fish groups. Also, fish fed diets supplemented with both algae at $5 \%$ had the best survival rate (SR) percentage (100\%)

The results of feed utilization appeared that, no significant differences were detected $(\mathrm{P}>0.05)$ among supplemented fish groups for feed intake (FI). On the other hand, FCR of experimental fish groups was affected significantly $(\mathrm{P} \leq 0.05)$ by algae supplementation. The lower FCR ratio was obtained by D3 (1.24), while the higher FCR was detected by control diet (D1, 1.74). Moreover, PER and PPV were influenced significantly $(\mathrm{P} \leq 0.05)$ by using different levels of Ulva lactuca and Pterocladia capillacea. The preferable values of PER and PPV were observed with Ulva lactuca supplementation at 5 and $2.5 \%$, respectively. Our data are in agreement with those reported for Nile tilapia (Oreochromis niloticus) using 5\% U. rigida dietary supplementation for better growth and nutrient utilization [13]. Diler et al. [31] found that the inclusion of Ulva meal at 5 to $15 \%$ replacing wheat meal in carp diets improved the growth parameters and could be acceptable for common carp. Moreover, Guroy et al. [32] found that higher values were obtained for weight gain of Nile tilapia fed on diets supplemented with various levels of Ulva meal (5 to 10\%). Besides, feeding trial with previous Ulva meal for mullet (Mugil cephalus) was successful and related with higher growth performance, feed intake and protein utilization [33]. These findings confirm the positive effects reported on promoted growth performance and survival rate of gilthead seabream fry (S. aurata) with the addition of 5\% Ulva meal (UM) or $10 \%$ pterocladia meal (PM) to their diets which probably due to the relatively high protein and mineral contents and good essential amino acid profile of both algae meals [10]. On the other hand, Kissil et al. [34] observed no significant effect $(\mathrm{P}>0.05)$ after the inclusion of Ulva meal in the diets of grow-out gilthead seabream on growth rate but found a slightly better protein utilization at the highest tested level of $8 \%$. Wassef et al. [35] indicated that feeding seabass only at low level (5\%) of Ulva or Ptercladia meal produced the best growth, feed utilization, nutrient retention, and survival rates among all the dietary groups. Elmorshedy [36] reported that, there were positive trends between protein efficiency ratio (PER) and seaweeds inclusion levels in the diet up to the level of $14 \%$.

\section{Body composition of Nile tilapia}

Effect of Ulva lactuca and Pterocladia capillacea algae 
supplementation on Nile tilapia body composition is shown in Table 4. Data of this experiment explained that, the addition of algae had no significant influence $(\mathrm{P}>0.05)$ on $\mathrm{DM}, \mathrm{CP}$, lipids and ash content of fish body composition. Fish fed with the algae diets recorded relatively higher dry matter, protein and ash but lower lipids content than those of the respective control diet. Fish fed diet supplemented with Ulva lactuca at 5\% had a higher content of CP (59.62\%) and lower lipid content $(8.55 \%)$ of fish body composition compared to other experimental fish groups. In agreement with our data, Olvera-Novoa et al. [37] investigated that the body composition of Nile tilapia was not clearly affected by the inclusion of spirulina from 20 to $100 \%$ in experimental diets. Besides, the partial replacement of fish meal by Gracilaria bursa-pastoris and Ulva rigida up to $10 \%$, and by Gracilaria cornea at $5 \%$ did not affect the whole-body composition of sea bass, whereas fish fed $10 \%$ Gracilaria cornea exhibited higher ash content [10]. Carcass protein content in the present study increased and lipid content decreased gradually with increasing Ulva and pterocladia algae level in the diet to $5 \%$ without significant differences. This agrees with the results obtained by Azaza et al. [38] who observed that increasing supplemental levels of Ulva rigida meal decrease carcass lipid content of the Nile tilapia. In contrast, the feeding of algae was reported to enhance the body lipid in red sea bream [39]. Ulva species have a good vitamin and mineral content and are especially rich in ascorbic acid or vitamin C $[11,12]$. Vitamin $C$ is considered as a promoter for lipid metabolism, which may effects on body metabolism and composition. The pervious reasons may result in the alteration of body nutrients deposition in fish, and therefore decrease carcass lipid and save a protein nutrient for tissue development $[40,41]$.

\section{Biochemical blood parameters}

Table 5 explained the hematological and biochemical parameters of Nile tilapia fingerlings fed on the experimental diets is presented in.

\begin{tabular}{|l|c|c|c|c|c|c|c|}
\hline \multirow{2}{*}{ Items } & Initial & \multicolumn{7}{|c|}{ Diets } & \multirow{2}{*}{ Fish } \\
\cline { 3 - 8 } & & $\begin{array}{c}\mathbf{D}_{\mathbf{1}}, \\
\text { Control }\end{array}$ & $\mathbf{D}_{\mathbf{2}}$ & $\mathbf{D}_{\mathbf{3}}$ & $\mathbf{D}_{\mathbf{4}}$ & $\mathbf{D}_{\mathbf{5}}$ & SE$^{*}$ \\
\hline Dry matter & 24.50 & 26.54 & 26.98 & 27.24 & 26.87 & 27.10 & 0.25 \\
\hline Crude protein & 55.12 & 58.21 & 58.67 & 59.62 & 57.65 & 58.68 & 2.36 \\
\hline Lipids & 9.21 & 8.59 & 8.67 & 8.55 & 8.96 & 8.76 & 0.54 \\
\hline Ash & 13.25 & 14.21 & 13.68 & 14.02 & 14.25 & 14.26 & 0.20 \\
\hline
\end{tabular}

Table 4: Effect of experimental diets on Nile tilapia body composition (\%, on DM basis).

\begin{tabular}{|c|c|c|c|c|c|c|}
\hline \multirow[t]{2}{*}{ Items } & \multicolumn{5}{|c|}{ Treatments } & \multirow{2}{*}{ SE* $^{*}$} \\
\hline & Control, D1 & D2 & D3 & D4 & D5 & \\
\hline \multicolumn{7}{|l|}{ Blood picture } \\
\hline T. W. BC ${ }^{1} \mathrm{~s}\left(10^{3} / \mathrm{mm}^{3}\right)$ & 22.35 & 21.54 & 23.54 & 22.01 & 22.78 & 2.15 \\
\hline T. R. BC ${ }^{2} \mathrm{~s}\left(10^{6} / \mathrm{mm}^{3}\right)$ & 3.54 & 3.65 & 3.47 & 3.21 & 3.84 & 0.10 \\
\hline $\mathrm{Hb}^{3}(\mathrm{~g} / \mathrm{dl})$ & 6.70 & 7.21 & 7.24 & 6.89 & 6.84 & 0.44 \\
\hline \multicolumn{7}{|c|}{ Biochemical parameters Protein } \\
\hline Total Protein (g/dl) & 3.21 & 2.89 & 3.14 & 3.22 & 3.34 & 0.34 \\
\hline Albumin (g/dl) & 1.34 & 1.45 & 1.39 & 1.28 & 1.54 & 0.08 \\
\hline Globulin (g/dl ) & 1.87 & 1.44 & 1.75 & 1.94 & 1.80 & 0.12 \\
\hline \multicolumn{7}{|l|}{ Liver function } \\
\hline $\mathrm{AST}^{5}(\mathrm{U} / \mathrm{L})$ & 54.21 & 55.32 & 53.45 & 54.25 & 56.31 & 3.14 \\
\hline $\operatorname{ALT}^{6}(\mathrm{U} / \mathrm{L})$ & 22.54 & 23.10 & 24.53 & 22.45 & 21.03 & 0.18 \\
\hline
\end{tabular}

*Means in the same columns having different superscript letters were significantly different at 0.05 levels.

**TWBC ${ }^{1}=$ Total White Blood Cell, $\mathrm{TRBC}^{2}=$ Total Red Blood Cells, $\mathrm{Hb}^{3}=$ Hemoglobin Concentrations; $\mathrm{ALT}^{5}=$ Alanine Aminotransferase and $\mathrm{AST}^{6}=$ Aspartat Amino Transferase.

Table 5: Hematological and biochemical parameters of Nile tilapia fed on the experimental diets. Aminotransferase.
Algae supplementation had no significant $(\mathrm{P}>0.05)$ on blood serum $\mathrm{WBC}, \mathrm{RBC}$ and $\mathrm{Hb}$ concentrations with different levels and strain. There were slight increases with supplemented Ulva for the pervious parameters compared to other experimental diets. Also, blood protein fractions as albumin, globulin and total protein were not affected significantly $(\mathrm{P}>0.05)$ by both of algae addition. The higher blood concentration of total protein and albumin were found with D5 (3.34 and $1.54 \mathrm{~g} / \mathrm{dl}$, respectively) while, a higher blood concentration was obtained by D4 (1.94 g/dl).The results explained that, the function of liver through the blood ALT and AST concentrations was insignificantly influenced $(\mathrm{P}>0.05)$ by Ulva and pterocladia addition. Our results agree with Promya and Chitmant [42] who reported that fingerlings which received $5 \% A$. platensis diets had higher values for red and white blood cell counts and immunity stimulating capacity. Jongkon and Chanagun [43] found that catfish fed with 5\% Spirulina platensis (SD) exhibited higher red and white blood cell counts and a higher immunity stimulating capacity (measure by a lysozyme activity assay). Also, Fingerlings, which received feed 5\% SD had higher values for red and white blood cell counts. Increased in WBC and RBC refer that Ulva and pterocladia in the diet may benefit the immune system in Nile tilapia as well. Ulva spp contains carotenoids, which affect the health of fish, specifically improving the ability to resistant the infections via the reduction of stress [44]. Also, this results attributed to the algae contain a different minerals and vitamins that improve the immunity of the fish.

\section{Conclusions}

The present work suggests that using red alga $P$. capillacae or green alga $U$. lactuca, at the optimum inclusion levels, in Nile tilapia diets is feasible which will lead to improved growth performance, feed utilization, survival rate and fish body composition. Moreover, the dietary supplements can impart beneficial effects on immunity and liver activity.

\section{Acknowledgments}

The authors wish to thank the team works of the faculty of agriculture, Tanta University, Egypt and Faculty of Aquatic and Fisheries Sciences, Kafrelsheikh University, Egypt for their technical assistance during this study.

\section{References}

1. Ratana-arporn $P$, Chirapart A (2006) Nutritional evaluation of tropical green seaweeds Caulerpa lentillifera and Ulva reticulate. Kasetsart J Nat Sci 40: 75-83.

2. Herbreteau FL, Coiffard JM, Derrien A, De RoeckHoltazahuer Y (1997) The fatty acid composition of five species of macro algae. Bot Mar 40: 1-6.

3. Sanchez-Machado DI, Lopez-Cervantes J, Lopez-Hern'andez J, PaseiroLosada P (2004) Fatty acids, total lipid, protein and ash contents of processed edible seaweeds. Food Chem 85: 439-444.

4. Chan JCC, Cheung PCK, Ang PO (1997) Comparative studies on the effect of three drying methods on the nutritional composition of seaweeds Sargassum hemiphyllum (Turn) C. Ag. J Agri Food Chem 45: 3056-3059.

5. Norziah $\mathrm{MH}$, Ching ChY (2000) Nutritional composition of edible seaweed Gracilariachanggi. Food Chem 68: 69-76.

6. Chapman VJ, Chapman DJ (1980) Seaweeds and their uses

7. Lahaye M (1991) Marine algae as sources of fibers: determination of soluble and insoluble dietary fiber contents in some sea vegetables. J Sci Food Agri 54: 587-594.

8. Shields RJ, Lupatsch I (2012) Algae for aquaculture and animal feeds Technikfolgenabschätzung-Theorie und Praxis 21: 23-37.

9. Mustafa MG, Nakagawa H (1995) A review: dietary benefits of algae as an additive in fish feed. Israel J Aquacult 47: 155-162.

10. Wassef EA, El-Sayed AFM, Kandeel KM, Sakr EM (2005) Evaluation of 
Citation: Khalafalla MM, El-Hais AMA (2015) Evaluation of Seaweeds Ulva rigida and Pterocladia capillaceaas Dietary Supplements in Nile Tilapia Fingerlings. J Aquac Res Development 6: 312. doi:10.4172/2155-9546.1000312

Pterocladia and Ulva meals as additives to gilthead seabream Sparus aurata diets. Egypt J Aquat Res 31: 321-332.

11. Valente LMP, Gouveia A, Rema P, Matos J, Gomes EF, et al. (2006) Evaluation of three seaweeds Gracilaria bursa-pastoris, Ulva rigida and Gracilaria cornea as dietary ingredients in European sea bass Dicentra rchuslabrax juveniles. Aquaculture 252: 85-91.

12. Ortiz J, Romero N, Robert P, Araya J, Lopez- Herna'ndez J, et al. (2006) Dietary fiber, amino acid, fatty acid and tocopherol contents of the edible seaweeds Ulva lactuca and Durvillaea antarctica. Food Chem 9: 98-104.

13. García-Casal MN, Pereira AC, Leets I, Ramírez J, Quiroga MF (2007) High iron content and bioavailability in humans from four species of marine algae. $\mathrm{J}$ Nutr 137: 2691-2695

14. Ergün S, Soyutürk M, Güroy B, Güroy D (2009) Merrifield, Influence of Ulva meal on growth, feed utilization and body composition of juvenile Nile tilapia (Oreochromis niloticus) at two levels of dietary lipid. Aquacultint 17: 355-361.

15. Güroy D, Güroy B, Merrifield DL, Ergün S, Tekinay AA, et al. (2011) Effect of dietary Ulva and Spirulina on weight loss and body composition of rainbow trout, Oncorhynchus mykiss (Walbaum), during a starvation period. J Anim Physiol Anim Nutr (Berl) 95: 320-327.

16. Wassef EA, El Sayed AM, Kandeel KM, Mansour HA, Sakr EM (2002) Effect of feeding Pterocladia and Ulva meals in diets for gilthead bream Sparus aurata. Cahiers Options Mediterranean's.

17. Bottalico A, Foglie CID, Fanelli M (2008) Growth and reproductive phenology of Pterocla diellacapillacea (Rhodophyta: Gelidiales) from the southern Adriatic Sea. Botanica Marina 51: 124-131.

18. Shimeino S, Masumoto T, Hujita T (1993) Alternative protein sources for fish meal diets of young yellow tail. Nippon Suisan Gakkaishi 59: 137-143.

19. NRC (1993) Nutrient requirements of fish. National Academy Press Washington DC, USA.

20. Hepher B, Liao IC, Cheng SH, Haseih CS (1983) Food utilization by red tilapiaEffect of diet composition, feeding level and temperature on utilization efficiency for maintenance and growth. Aquaculture 32: 255-272.

21. Jauncey K, Ross B (1982) A guide to tilapia feeds and feeding Ins. Aquaculture Univ, Scotland, U.K.

22. AOAC (2000) Association of Official Analytical Chemists. Official Methods of Analysis.AOAC, Arlington, Virginia, USA

23. APHA American Public Health Association (1985) Standard methods for the examination of water and waste. 12th addition, Inc. New York.

24. Stoskopf MK (1993) Fish Medicine, WB Saunders Company, Harcourt.

25. Zinkl JG (1986) Veterinary Hematology, Philadelphia, Paihea and Fibiger, 256260.

26. Dacie SIV, Lewis SM (2006) Practical Haematology. 10th ed., Churchil Livingstone, London.

27. Henry RJ (1964) Colorimetric determination of total protein. In: Clinical Chemistry. Harper and Row Publ., New York, USA

28. Reitman S, Frankel S (1957) A colorimetric method for the determination of serum glutamic oxalacetic and glutamic pyruvic transaminases. Am J Clin Pathol 28: 56-63.

29. SPSS (1997) Statistical package for the social sciences, Versions 6 , SPSS in Ch, Chi-USA.

30. Duncan MB (1955) Multiple ranges and multiple F-tests. Biometrics 11:1-42

31. Diler IA, Tekinay A, Guroy D, Guroy BK, Soyuturk M (2007) Effects of Ulva rigida on the growth, Feed intake and body composition of Common Carp. Cyprinus carpio L. J Biol Sci 7: 305-308.
32. Guroy BK, Cirik, Guroy S, Sanver D, Tekiny AA (2007) Effects of Ulva rigida and Cystoseira barbata meals as a feed additive on growth performance, feed utilization and body composition of Nile tilapia, Oreochromis niloticus. Turkey $\mathrm{J}$ Vet Anim Sci 31: 91-97.

33. El Masry MH, Eissa MA, Mikhail FR (2001) Evaluation of five supplementary feeds for grey mullet Mugil cephalus fry. Egypt $J$ Nutrition and Feeds 4: 731 741.

34. Kissil GW, Lupatsch I, Neori A (1992) Approaches to fish feed in Israeli mariculture as a result of environmental constraints.

35. Wassef EA, El-Sayed AM, Eman M, Sakr (2013) Pterocladia (Rhodophyta) and Ulva (Chlorophyta) as feed supplements for European seabass Dicentrarchuslabrax L., fry. J Appl Phycol 25: 1369-1376.

36. Elmorshedy I (2010) Using of algae and seaweeds in the diets of marine fish larvae.

37. Olvera-Novoa MA, Dominguez-Cen IJ, Olivera Castillo L, Martinez-Palacios CA (1998) Effects of the use of the microalga Spirulina maxima as fishmea replacements in diets for tilapia, Oreochromis mossambicus, Peters, fry. Aquac. Res. 29: 709-715.

38. Azaza MS, Mensi F, Ksouri J, Dhraief MN, Brini B, et al. (2008) Growth of Nile tilapia Oreochromis niloticus $L$ fed with diets containing graded levels of green algae Ulva meal (Ulva rigida) reared in geothermal waters of southern Tunisia, Journal of Applied Ichthyology 24: 202-207.

39. Mustafa MG, Wakamatsu S, Takeda T, Umino T, Nakagawa H (1995) Effects of algae meal as feed additive on growth, feed efficiency and body composition in red sea bream. Fishery Science 61: 25-28.

40. Miyasaki T, Sato M, Yoshinaka R, Sakaguchi M (1995) Effect of vitamin C on lipid and carnitine metabolism in rainbow trout. Fish Sci 61: 501-506.

41. Om HJA, Yoshimatsu T, Hayashi M, Umino T, Nakagawa H, et al. (2003) Effect of dietary vitamins $C$ and $E$ fortification on lipid metabolism in red sea bream Pagrus major and black sea bream Acanthopagrusschlegeli. Fish Sci 69: 1001 1009 .

42. Promya J, Chitmant C (2011) The effects of Spirulina platensis and Cladophora algae on the growth performance, meat quality and immunity stimulating capacity of the African Sharptooth Catfish (Clarias gariepinus). Int J Agri Bio 13: $77-82$

43. Jongkon P, Chanagun C (2011) The effects of Spirulina platensis and Cladophora. Algae on the Growth Performance, Meat Quality and Immunity Stimulating Capacity of the African Sharptooth Catfish (Clarias gariepinus). Int J Agric Biol 13: 77-82.

44. Nakono T, Yamaguchi T, Sato M, Iwama GK (2003) Biological Effects of Carotenoids in Fish, International Seminar "Effective Utilization of Marine Food Resource", Songkhla, Thailand. 